\section{Inwencja tekstowa. Renesansowe antecedencje intertekstualności}

Wojciech Ryczek

TEKSTY DRUGIE 2018, NR 5, S. 329-351

DOI: $10.18318 /$ td.2018.5.20
Publikacja powstała

w ramach grantu naukowego Politropia: wczesnonowożytne teorie i koncepcje figuratywności, finansowanego ze środków Narodowego Centrum Nauki przyznanych na podstawie decyzji numer DEC-2013/11/D/HS2/04529.
Dojęcie intertekstualności (intertextualité), wynalezione prawie pół wieku temu przez Julię Kristevą ${ }^{1}$ a poważnie zadłużone inwencyjnie w koncepcji słowa dialogicznego Michaiła Bachtina, trafiło niemal od razu do słownika terminów literackich. Mimo nieustalonego do końca i niezbyt wyraźnie sprecyzowango znaczenia oraz otwartego pytania o zakres relacji intertekstualnych, wydawało się trafnie określać zjawisko występujące w literaturze co najmniej od czasów Homera, a mianowicie

1 J. Kristeva Séméiotiké. Recherches pour une sémanalyse, Seuil, Paris 1969. Por. krytyczne omówienia tego pojęcia w znaczeniu, jakie nadała mu autorka; J. Culler Presupozycje i intertekstualność, przeł. K. Rosner, "Pamiętnik Literacki” 1980 z. 3, S. 297-312; L. Hutcheon Ironia, satyra, parodia - o ironii wujęciu pragmatycznym, przeł. K. Górska, "Pamiętnik Literacki" 1988 z. 1, s. 335-336; M. Głowiński O intertekstualności, „Pamiętnik Literacki" 1986 z. 4, S. 75-100; L. Jenny Strategia formy, przeł. K. i J. Faliccy, "Pamiętnik Literacki” 1988 z. 1, s. 265-295; S. Balbus Między stylami, Universitas, Kraków 1993, s. 37-42; R. Nycz Intertukstualność i jej zakresy: teksty, gatunki, światy, w: tegoż Tekstowyświat. Poststrukturalizm a wiedza o literaturze, wyd. 2, Universitas, Kraków 2000, s. 79-109.

\section{Wojciech Ryczek -} dr, kierownik grantu Politropia:wczesnonowożytne teorie $i$ koncepcje figuratywności, finansowanego przez NCN (DEC-2013/11/D/ HS2/04529). Zajmuje się historią i teorią retoryki (zwłaszcza problematyką szeroko pojętej figuratywności), literaturą nowołacińską XVI-XVII wieku, historią idei. Ostatnio opublikował monografię Antystrofa dialektyki. Teoria retoryczna Bartłomieja Keckermanna,Toruń 2016. Kontakt: wojtek. ryczek@interia.pl 
rozmaitego rodzaju uzależnienia - genologiczne, inwencyjne, elokucyjne - jednych tekstów od drugich. Nie przeszkadzała w tym ani nadmierna ogólność (a nawet ogólnikowość), ani wyrazista schematyczność tego pojęcia. Chociaż miało ono proweniencję postrukturalistyczną, a jego genezę można wiązać z próbami przezwyciężenia strukturalistycznych ograniczeń, to samo zjawisko problematyzowane było już w niektórych podręcznikach poetyki czy retoryki i opisywane za pomocą kategorii pochodzących ze słowników tych dwóch sztuk słowa. Nie wszystkie z tych idei czy koncepcji dają się sprowadzić do prostej alegacji w rozumieniu Gisèle Mathieu-Castellani, gdyż ich autorzy wielokrotnie eksponowali znaczenie tekstowego przetworzenia szeroko rozumianego intertekstu w procesie twórczej imitacji i emulacji (współzawodnictwa) ${ }^{2}$.

Propagowanie nowych interpretacji biblijnych w okresie reformacji wiązało się z dynamicznym rozwojem kaznodziejstwa, któremu towarzyszyła refleksja metateoretyczna. Rekonstruując pojęcie inwencji tekstowej, odnalezione w stosunkowo niewielkim (w porównaniu z innymi rozprawami tego autora) traktacie Bartłomieja Keckermanna (1572-16o9), profesora filozofii w Gimnazjum Akademickim w Gdańsku, Retoryka kościelna, czyli sztuka tworzenia i wygtaszania świętych kazań (Rhetorica ecclesiastica, sive ars formandi et habendi conciones sacras, Hanau 160o)3 ${ }^{3}$, opisuję tę kategorię w perspektywie szeroko zakrojonego programu renowacji homiletyki pod znakiem powrotu do kazania jako zdyscyplinowanego retorycznie komentarza do wybranego

2 Por. G. Mathieu-Castellani Intertextualité et allusion. Le régime allusifchez Ronsard, "Littérature” 1984, S. 24-36; A. Fulińska Renesansowa aemulatio: alegacja czy intertekstualność?, „Teksty Drugie" 1997 nr 4, s. 5-15, tu szczególnie polemika z M. Głowińskim, zawężającym pojęcie alegacji do "odwołań tekstowych niełączących się z żywiołem dialogiczności" (O intertekstualności, s. 90-91), s. 5-6. Warto wspomnieć, że Mathieu-Castellani łączy aluzję również z figurami retorycznymi opartymi na niedopowiedzeniu i zamierzonej wieloznaczności, np. alegorią, elipsą czy synekdochą. Por. także S. Balbus Intertekstualność a proces historycznoliteracki, Wydawnictwo Naukowe UJ, Kraków 1990, s. 103-107.

Por. B. Nadolski Życie i działalność naukowa uczonego gdańskiego Bartłomieja Keckermanna. Studium z dziejów Odrodzenia na Pomorzu, PWN, Toruń 1961, s. 118-120; D.K. Shuger Sacred Rhetoric. The Christian Grand Style in the English Renaissance, Princeton University Press, Princeton, NJ 1988, s. 84-92; T.M. Conley Rhetoric in the European Tradition, The University of Chicago Press, Chicago-London 1990, s. 158-159; J.S. Freedman The Career and Writings of Bartholomew Keckermann (d. 1609), "Proceedings of the American Philosophical Society” 1997 Vol. 141, No. 3, s. 341; H. Hotson Commonplace Learning. Ramism and its German Ramifications, 1543-1630, Oxford University Press, Oxford 2007, s. 163; P. Mack A History of Renaissance Rhetoric 1380-1620, Oxford University Press, Oxford 2011, s. 274-275; W. Ryczek Antystrofa dialektyki. Teoria retoryczna Bartłomieja Keckermanna, Wydawnictwo UMK, Toruń 2016, s. 42-43. 
fragmentu Pisma. Lektura (interpretacja) retoryczna stanowi w tej koncepcji ośrodek sztuki inwencyjnego odkrywania nowych znaczeń i wynajdywania prawdopodobnych argumentów.

Keckermann rozpoczął pracę nad swoim podręcznikiem homiletyki podczas studiów z teologii w Collegium Sapientiae w Heidelbergu pod okiem wybitnego teologia i kaznodziei Daniela Toussaint (1541-1602). W tym czasie pomagał innym studentom w ćwiczeniach homiletycznych. Czytał także rozprawy innych autorów z zakresu sztuki kaznodziejskiej, zwłaszcza Erazma z Rotterdamu (Kaznodzieja, czyli o sztuce głoszenia kazań, Ecclesiastes, sive de ratione concionandi, 1535), biskupa Werony Agostina Valiera (Retoryka kościelna, Rhetorica ecclesiastica, 1570), hiszpańskiego dominikanina Ludwika z Grenady (Retoryka kościelna, czyli o sztuce głoszenia kazań, Ecclesiastica rhetorica, sive de ratione concionandi, 1576), franciszkanina Diega de Estella (O sztuce głoszenia kazań, czyli retoryce kościelnej, De ratione concionandi, sive rhetorica ecclesiastica, 1576), Diega Péreza de Valdivia (Oświętej sztuce głoszenia kazań, De sacra ratione concionandi, 1588), Jakuba Zabarelli, Zachariasza Ursinusa i Abrahama Bucholztera. Na podstawie lektury teoretycznych rozpraw i słuchania kazań wygłaszanych w kościołach stolicy Palatynatu opracował podręcznik, w którym zamierzał uporządkować metodycznie sztukę homiletyki. Rozprawę gdańskiego humanisty przedrukowywano sześciokrotnie w latach 16oo-1616 w oficynie wydawniczej zaprzyjaźnionego z nim Wilhelma Antoniusa ${ }^{4}$.

Trzeba rozpocząć od definicji retoryki kościelnej. Jest ona sztuką przekonywania (ars persuadendi) kościoła Chrystusowego do rzeczy koniecznych do osiagnięcia zbawienia 5 . Perswazja na gruncie wymowy określonej jako kościelna nabiera szczególnego znaczenia, gdyż służy przede wszystkim objaśnianiu doktryny chrześcijańskiej. Przez kościół (ecclesia) należy tu rozumieć, zgodnie z etymologią tego słowa i poglądami eklezjologicznymi reformatorów, zgromadzenie lokalnej wspólnoty wiernych pod przewodnictwem pastora. Johann Reuchlin (1455-1522), promotor renesansowych studiów nad językiem hebrajskim, określił kaznodzieję, mówcę kościelnego (orator ecclesiasticus) w traktacie o sztuce głoszenia kazań (Liber congestorum de arte

4 L.D. Green, J.J. Murphy Renaissance Rhetoric Short Title Catalogue: 1460-1700, Ashgate, Aldershot 2006, s. 254.

5 B. Keckermann Rhetoricae ecclesiasticae sive artis formandi et habendi conciones sacras libri duo methodice adornati per praecepta et explicationes, Hanoviae: apud Petrum Antonium 1619, s. 27: "Rhetorica ecclesiastica est ars persuadendi Ecclesiae Christi res ad salutem necessarias". Dalej posługuję się skrótem RE, zachowując paginację starodruku. Wszystkie tłumaczenia, o ile nie zaznaczono inaczej, pochodzą ode mnie. 
praedicandi, Pforzheim 1504) ${ }^{6}$ mianem „męża religijnego, biegłego w wymowie" (vir religiosus, dicendi peritus), przenosząc tym samym słynną definicję idealnego mówcy Kwintyliana (formuła Katona Starszego: vir bonus, dicendi peritus, Inst. orat. XII 1,1) na płaszczyznę rozważań nad wymową kościelną. Dla Keckermanna perswazja obejmuje umiejętność nauczania (docere), a następnie wzbudzania uczuć (movere). Obie powinności kaznodziei opatruje humanista odwołaniem do zasad homiletyki wyłożonych przez św. Augustyna w rozprawie $O$ nauce chrześcijańskiej (De doctrina christiana), według którego mówca kościelny to przede wszystkim "komentator i nauczyciel Pisma Świętego" (De doc. christ. IV 4,6). Keckermann wykazuje charakterystyczną powściągliwość w przenoszeniu gotowych koncepcji z antycznej teorii retorycznej do usystematyzowanego wykładu sztuki głoszenia kazań. Wszystkie one muszą zostać odpowiednio wcześniej zreinterpretowane.

Cel retoryki kościelnej może być ujmowany jako zewnętrzny (jest nim ogólnie pojęta perswazja) oraz wewnętrzny, który prowadzi do powstania mowy kościelnej (oratio ecclesiastica), czyli kazania. Gdański humanista wyjaśnia, że logicy określają mianem celu wewnętrznego konkretne dzieło, stworzone w wyniku praktycznego zastosowania przepisów danej sztuki. Posługuje się także obrazowym porównaniem ${ }^{8}$. Zewnętrznym celem architektury jest dom, wewnętrznym zaś ukończony budynek, w którym można od razu zamieszkać. Analogicznie przedstawia się ta kwestia w przypadku kazania i perswazji w retoryce kościelnej. To rozróżnienie dwóch celów bierze swój początek z przeciwstawienia sobie ogólnej i uniwersalnej reguły oraz jej jednostkowej i skonkretyzowanej realizacji przedmiotowej. Każda mowa

6 G.R. Evans The Ars Praedicandi of Johannes Reuchlin (1455-1522) "Rhetorica” 1985 3, s. 99-104. Por. definicję wymowy kościelnej podaną przez Reuchlina: „Ars praedicandi est facultas hominem alliciendi ad virtutes et contemplationem divinam ex sanctarum scripturarum promulgatione. Praedicator est vir religiosus dicendi peritus, auctoritate superioris ecclesiastico pulpito praefectus".

7 "Externus est persuasio, quae duo sub se continet, quorum primum est docere, secundum animos seu affectus movere. Atque hi duo sunt necessarii et essentiales fines propositi oratori ecclesiastico, qui si alterum ex his negligit, numquam suo officio recte defungetur", RE, s. 28.

8 "Internum finem vocant logici ipsum propinquum opus artis, sicut externum vocant huius operis usum et utilitatem. Opus nimirum architectonicae est, exempli gratia, domus et haec eadem idcirco dicitur finis internus. Externus autem finis est huius operis utilitas, domus videlicet commoda inhabitatio. Merito ergo a nobis concio ipsa dicitur finis internus rhetoricae ecclesisticae, quia est opus rhetoris ecclesiastici, quod operando efficit, persuasio autem huius operis effecti usus et utilitas in auditore", RE, s. 29. 
urzeczywistnia wobec tego przynajmniej niektóre reguły abstrakcyjnie pojętej sztuki przekonywania.

Zasada podziału dychotomicznego znajduje swe zastosowanie również w przypadku wykładu retoryki kościelnej”, która składa się z dwóch części: przedstawienia reguł tworzenia kazania (głównie inwencji i dyspozycji) oraz omówienia przepisów dotyczących jego wygłoszenia (operowanie głosem i gestem). Decyduje ono ostatecznie o skuteczności perswazji i ukazuje stopień opanowania przez kaznodzieję sztuki retorycznej. Ten podział retoryki kościelnej nie pokrywa się dokładnie z dwoma działami homiletyki wyróżnionymi przez św. Augustyna, a wskazanymi przez Keckermanna jako analogiczne względem jego systematyzacji umiejętności tworzenia i wygłaszania kazań. Punktem wyjścia była dla afrykańskiego biskupa egzegeza biblijna:

Wszelki wykład Pisma opiera się na dwóch podstawach: jedną jest wynajdywanie [modus inveniendi] tego, co trzeba dokładnie zrozumieć, drugą jest przedstawienie [modus proferendi] tego, co zostało zrozumiane. Najpierw zastanówmy się nad wyszukiwaniem, a później zajmiemy się przedstawieniem. ${ }^{10}$

Retoryka chrześcijańska św. Augustyna ma znacznie szerszy zakres odniesienia niż retoryka kościelna Keckermanna. Została bowiem podporządkowana hermeneutyce Pisma Świętego, ujmowanej jako umiejętność odkrywania ukrytych znaczeń ksiąg biblijnych. W koncepcji augustiańskiej sztuka wymowy staje się przydatna dopiero wtedy, gdy pojawia się potrzeba językowej artykulacji sensu uchwyconego w trakcie wnikliwej lektury Biblii. Domeną hermeneutyki biblijnej są rzeczy (res), czyli pojęcia i problemy, z jakimi stykamy się na kartach świętych ksiąg. Retoryka ogranicza się natomiast do umiejętności posługiwania się słowami (verba), które mogą być właściwe (propria) lub przenośne (translata). Te ostatnie są najczęściej wieloznaczne i dlatego wymagają niekiedy objaśnienia.

9 "Ex hoc fine systema rhetoricae ecclesiasticae dividitur in duas partes, quorum prior est de recte formanda concione, posterior de concione pro suggesto recte habenda et enuncianda", RE, s. 29.

św. Augustyn De doctrina christiana. O nauce chrześcijańskiej, przeł., wstępem i komentarzem opatrzył J. Sulowski, Warszawa 1989, s. 10-11; por. W. Ryczek De rhetorica christiana św. Augustyna: między filologiq̨ a filozofią, w: Studia rhetorica, red. M. Choptiany, W. Ryczek, Księgarnia Akademicka, Kraków 2011, s. 215-216. 
Hermeneutyka nie miała, jak zauważyła Rita Copeland, jasno określonego statusu pośród dyscyplin tworzących system siedmiu sztuk wyzwolonych. Określone przez nią kompetencje filologiczne były po części przydzielane sztukom, które nazywano „trywialnymi” (trivium), chociaż to one pozwalały rozwijać umiejętność mówienia, traktowaną jako podstawowy wyznacznik człowieczeństwa:

Gramatyka umieszcza czytelnika (studenta) w przedkrytycznym otoczeniu tekstu, retoryka daje czytelnikowi percepcyjne i krytyczne narzędzia, dzięki którym rozumie warunki tego otoczenia i dlatego może nad nimi zapanować. Retoryka jako ćwiczenie z mądrości praktycznej wspiera również model hermeneutyki; czytelnik pozostaje zaangażowany w dialektyczną relację z tekstem, gdyż interpretacja została połączona z aplikacją. ${ }^{11}$

Zbliżenie gramatyki i retoryki spowodowało we wczesnym średniowieczu przekształcenie inwencji w gotowy zestaw narzędzi analityczno-interpretacyjnych. Reguły tworzenia tekstu stały się regułami jego odczytywania. Retoryka przyjęła w ten sposób postać „produktywnej dyskursywnie 'gramatyki' czytania". Święty Augustyn poszerzył znacznie wcześniej zakres inwencji o problematykę wyjaśniania i komentowania (tractatio) tekstu. Ta redefinicja funkcji pociągnęła przekształcenie jej w procedurę hermeneutyczną. Wynajdowanie argumentów zaczęło oznaczać tym samym lekturę Pisma.

Usytuowanie kazania wobec tekstu biblijnego stanowi dla Keckermanna podstawę do wyróżnienia dwóch rodzajów tworzenia mów kościelnych. Pierwszy zostaje określony jako swobodny (formatio libera) ${ }^{\mathbf{1 2}}$ i dotyczy sytuacji, w której kaznodzieja naucza o danej rzeczy bez odwołania do konkretnego, odczytanego wcześniej, fragmentu Pisma Świętego, jak np. wtedy, gdy mówiąc o miłości (caritas), tworzy jej pochwałę (enkomium), omawia przyczyny sprawcze w odniesieniu do tej cnoty czy też wylicza przeszkody stojące na drodze do jej osiągnięcia. Humanista zwraca uwagę, że tego rodzaju kazania nie są zbyt

11 R. Copeland Rhetoric, Hermeneutics and Translation in the Middle Ages. Academic Traditions and Vernacular Texts, Cambridge University Press, Cambridge 1991, s. 20; por. rozdz. 6. From antiquity to the Middle Ages II: rhetorical invention as hermeneutical performance, s. 154-158.

„Formatio concionis vel libera est, vel textualis. Libera est, quae non versatur circa certum aliquem Sacrae Scripturae textum, sed ex arbitrio oratoris de re ipsa instituitur, ut cum quis sine ullo textu praelecto, proponit agere exempli causa de caritate, recensens primo eius encomia et laudes, secundo causas efficientes, per quas ea virtus acquiritur, tertio impedimenta, quae nos in caritatis studio impedire queant et eiusmodi alia", RE, s. 30. 
często wygłaszane w kościołach ewangelickich. O wiele częściej występują u „kaznodziejów papieskich”, zwłaszcza w mowach wychwalających świętych i męczenników. Jako teoretyk homiletyki Keckermann nie wartościuje żadnego z tych dwóch sposobów opracowania kazania. Przywołuje poza tym przykład św. Jana Chryzostoma, który łączył je umiejętnie w swojej praktyce kaznodziejskiej, omawiając konkretny fragment zaczerpnięty z ksiąg biblijnych, a następnie rozwijając swobodnie argumentację wspierającą głoszoną tezę ${ }^{13}$.

Drugi typ tworzenia mowy kościelnej wiąże bardzo ściśle opracowanie kazania z lekturą wybranego fragmentu Pisma Świętego. Tworzenie tekstowe (formatio textualis) składa się ponadto z objaśnienia tekstu (textus tractatio) oraz ozdobienia sporządzonego komentarza (tractatorum exornatio). Pierwszy etap pracy nad kazaniem obejmuje w teorii retoryki kościelnej Keckermanna dwie komplementarne dziedziny ${ }^{14}$, a mianowicie inwencję tekstową (inventio textualis) i dyspozycję (dispositio textualis):

Tekstowe tworzenie kazania ma miejsce wtedy, gdy objaśnia się pewne określone "miejsce wspólne" albo odczytany słuchaczom tekst Pisma Świętego, do którego odnosi się następnie inwencję i dyspozycję kazania. Inwencja tekstowa jest wymyśleniem i obmyśleniem tego, co zgodnie z linią tekstu trzeba powiedzieć ludziom o samej rzeczy. Inwencja jest niejako materią albo samym czynnikiem materialnym kazania, dypozycja zaś formalnym. Zespala ona bowiem, że tak powiem, kości i ścięgna kazania odpowiednim połączeniem oraz łączy je swoimi „miejscami wspólnymi". Potem następuje przyozdobienie, które dodaje [mu] krwi, ciała, ożywczego tchnienia i zewnętrznej postaci. Dlatego jak malarz, gdy chce namalować obraz, obmyśla najpierw w umyśle wzór i zarysy, za których śladem podąża następnie ręka, tak kaznodzieja powinien obmyślić na

13 "Libera formatio concionis est non admodum hodie frequens in Evangelicis Ecclesiis, ideo de textuali hic potissimum nobis tractare propositum. Libera concionis formatio valde frequens fuit et est adhuc apud Pontificios concionatores, praesertim cum de laudibus Martyrum et Sanctorum perorant. Sed Evangelicae Ecclesiae textualem tractationem praetulerunt, motae cum aliis rebus, tum vero dicto Petri: „Qui loquitur, loquatur tantum eloquia Dei", nisi quod in concionibus Catecheticis libera illa concionandi ratio ex parte fuit retenta. Divus Chrysostomus mixtum quoddam habet concionandi genus, ut videlicet textum aliquem Scripturae enarret, postea argumentum aliquod certum libere persequatur", RE, s. 30-31.

14 "Textualis ergo formatio concionis duabus constat partibus, quarum prior est textus tractatio, posterior tractatorum exornatio. Tractatio textualis iterum habet duas partes, quarum prior est textualis inventio, posterior textualis dispositio", RE, s. 31. 
początku rzecz z uwagi na jej wartość, aby wygłoszenie kazania podążało następnie za śladem przedstawionego wzoru. ${ }^{15}$

Tradcyjną inwencję $e^{16}$ poszerza Keckermann o umiejętność interpretowania tekstu przy jednoczesnym ograniczeniu zakresu hermeneutyki funkcjonującej w obrębie retorycznej inwencji do ksiąg Pisma Świętego. Tekstowe opracowanie mowy kościelnej dopuszcza wprawdzie omawianie wybranego uprzednio "miejsca wspólnego", ale także ono powinno wspierać się głównie na „dowodach" skrypturystycznych. Inwencja określona przez Keckermanna jako tekstowa stanowi zespolenie tradycyjnej umiejętności wynajdywania argumentów z procedurą egzegetyczną ukierunkowaną na pojęciowe opracowanie idei oraz zagadnień (res) związanych z odczytanym wcześniej fragmentem Pisma. Głośna lektura tekstu splata się w przekonaniu humanisty nierozerwalnie ze sztuką objaśniania jego ukrytych znaczeń. Ważną rolę odgrywa w tym kontekście przywołanie kluczowej dla filozofii Stagiryty pary pojęć. Związek między znanymi ze sztuki retorycznej inwencją a dyspozycją, indeksowanymi dodatkowo określeniem tekstowa, odwzorowuje dynamiczną, a więc polegającą na aktywnym współoddziaływaniu na siebie dwóch elementów, relację między formą a materią. W tak zdefiniowanym schemacie pojęciowym inwencja pełni funkcję czynnika materialnego, związanego z wynajdywaniem nowych argumentów i gromadzeniem pojęć, dyspozycja zaś - czynnika formalnego, służącego strukturyzacji i hierarchizacji zgromadzonego materiału. Charakterystykę tych dwóch etapów tworzenia mowy w kategoriach zaczerpniętych bezpośrednio z filozofii Arystotelesa można rozwijać dalej, przywołując kolejne opozycje, dające wyprowadzić się z przeciwstawienia materii i formy, takie jak np. potencja - akt, szczegół ogół czy konkret - abstrakt.

„Textualis formatio concionis est, qua certus aliquis locus seu textus Sacrae Scripturae auditoribus prelectus tractatur, ad quem deinde concionis inventio et dispositio dirigitur. Inventio textualis est conceptio et excogitatio eorum, quae secundum textus praesentis ductum de re ipsa ad populum sunt dicenda. Inventio est instar materiae, seu est ipsum materiale concionis, dispositio autem est formale. Haec enim concionis ossa (ut sic dicam) et nervos apta compage vincit et suis locis aptat, accedit deinceps exornatio, quae sanguinem, carnem, calorum et colorem addit. Itaque sicut pictor, cum imaginem effingere vult, mente prius concipit exemplar et lineamenta, quorum deinde ductum manus sequitur, sic concionator res primo concipere pro dignitate debet, ut deinceps concionis pronuntiatio propositi exemplaris ductum sequatur", RE, s. 31-32. 
Osobną kwestię stanowią dwa obrazy wykorzystane przez Keckermanna w celu ilustracji działania inwencji. Retoryczne etapy konstrukcji tekstu zestawiono na zasadzie analogii z ciałem człowieka. Wydobyte dzięki inwencji w trakcie uważnej lektury Pisma argumenty tworzą solidny kościec kazania. Materia językowa, zróżnicowana za pomocą figur słów i myśli, pozwala przyjąć mu cielesną powłokę. Sztuka wymowy okazuje się tym samym tożsama ze swoistą anatomią tekstu. Porównanie inwencyjnego opracowania mowy do pracy malarza ma długą tradycję literacką (Cyceron, Kwintylian, średniowieczna koncepcja colores rhetorici). W przypadku reguł wymowy kościelnej, których przystępne wyłożenie znajduje się w centrum zainteresowania Keckermanna, tę analogię trzeba odczytywać w kontekście wymienionych powyżej pojęć z filozofii Arystotelesa. Ideą regulatywną w stosunku do całego procesu twórczego (malowania obrazu czy tworzenia tekstu wystąpienia kościelnego) jest idealny wzorzec obmyślony i przechowywany w umyśle artysty. Praca nad obrazem albo kazaniem ma charakter konceptualnego opracowania modelu, który stanie się podstawą dla późniejszej działalności artystycznej związanej z jego pełnym urzeczywistnieniem, wyposażeniem w zestaw cech konkretnych i niepowtarzalnych.

Epitet tekstowa (textualis), odnoszony przez Keckermanna do inwencji i dyspozycji, wymaga kilku słów komentarza. Może odnosić się do procedury egzegetycznej, podkreślając inwencyjno-elokucyjną zależność kazania od biblijnego tekstu. Mowa kościelna powstaje bowiem w wyniku naśladowania konkretnego fragmentu Pisma. Ma służyć jego szeroko rozumianej wykładni, umożliwiając nie tylko pełniejsze rozumienie odczytanych słów, ale także odniesienie ich do aktualnej sytuacji słuchaczy. Odwołanie do etymologii pozwala wydobyć z tego epitetu jeszcze jedno znaczenie, które odsyła do tkaniny (textus) splatanej z wielu włókien. Jeśli kazanie powiela tę mozaikową strukturę, to inkrustowane jest często biblijnymi cytatami i komentarzami do nich, które wyszły spod pióra późniejszych autorów, zwłaszcza ojców Kościoła i ich średniowiecznych oraz wczesnonowożytnych naśladowców. Przypomina z tego powodu kunsztowną tkaninę splecioną z dwóch rodzajów włókien, drogocennej nici biblijnego cytatu i prostej - a niekiedy też i ozdobnej - nitki komentarza.

Jeśli głównym celem kazania ma być poruszenie słuchaczy, kaznodzieja musi wówczas dołożyć wszelkich starań, aby inwencja koncentrowała się wokół rzeczy mogących budzić u nich zdziwienie i zachwyt:

Sam rozsądek i doświadczenie świadczy niewątpliwie o tym, że nieudolni są ci kaznodzieje, którzy wzbudzając jakieś uczucie, wybierają zbyt niskie 
i zimne [uczucia] albo tego rodzaju; gdy słuchacze ich słuchają, myślą zawsze sobie: to samo i ty mógłbyś powiedzieć na tym miejscu. Dlatego zdarza się, że ostatecznie są całkowicie porzuceni przez słuchaczy albo zamiast uczuć sprowadzają [na nich] sen. Jeśli umysł ludzki woli dzięki pewnej naturalnej właściwości rzeczy nieoczekiwane, rzadkie i takie, o których sądzi, że są ponad swe siły, to w przeciwnym razie niezwykle słabnie jego uwaga, gdy słucha wszystkiego, co jest niskie i zimne. Rzeczy powinny być jednak tak rzadkie, aby były przystępniejsze dla umysłu; te bowiem, które są z trudnością rozumiane przez ludzi, nie poruszają, ale odstręczają; nie pragnie się nieznanego. ${ }^{17}$

Pragnienie skutecznego oddziaływania na uczucia odbiorców prowadzi do reorganizacji inwencji retorycznej, ukierunkowania jej na wynajdywanie argumentów przykuwających uwagę. W wymowie zarówno u Cycerona, jak i św. Augustyna zaznacza się wyraźnie tendencja do przywoływania tego, co niezwykłe albo nieoczywiste ${ }^{18}$. Wiąże się ona w praktyce oratorskiej z wykorzystaniem rozmaitych strategii amplifikacji, które pozwalają na sublimację rzeczy przyziemnych i renowację utartych znaczeń. Efektywność tego modelu inwencji zależy jednak od subtelnego napięcia między niezwykłością wynalezionego argumentu a łatwością jego zrozumienia. Mówiąc innymi słowy, afektywna orientacja sztuki inwencyjnej nie może zdominować całkowicie funkcji dydaktycznej kazania. Uczucia mają bowiem otworzyć serce i umysł słuchacza na przystępny wykład nauki chrześcijańskiej.

Inwencja związana z mowami kościelnymi powinna być podporządkowana w całości krzewieniu pobożności. Podlega ona z tego powodu licznym delimitacjom w zakresie niektórych strategii dyskursywnych:

17 „Et certe ipse sensus et experientia testatur ingratos esse illos concionatores, qui affectum aliquem moturi, nimis humilia et frigida eligunt aut eiusmodi, quae cum audiunt auditores semper secum cogitant: eadem et tu potuisses hoc loco dicere. Unde fit, ut ab auditoribus vel plane tandem deserantur, vel pro affectibus somnum concilient. Siquidem humanus animus naturali quadam proprietate amat improvisa, rara et quae ipse putat esse supra vires suas, contra mirifice languescit in attentione, si omnia protrita et frigidiuscula audiat. Interim ita rarae debent esse res, ut sint intellectu facilimae quae enim a populo difficulter intelliguntur, illa non movent, sed absterrent; ignoti nulla cupido", RE, s. 34-35.

„De inventione doctrinae postea dicetur, illam debere esse popularem, sed inventio comparata ad movendos animos inprimis admirationem debet parere et idcirco abesse longius ab illis, quae protrita sunt et quae cuivis etiam plebeio alicui et rudi in mentem venire possint", RE, s. 34 . 
Skoro celem kazania jest pobudzenie dusz słuchaczy do religii i uświęcenia życia, to trzeba strzec się tych wszystkich rzeczy, które są sprzeczne z tym celem; takimi rzeczami są: żarty, niedorzeczne i zmyślone opowiastki, niezbyt poważne sposoby wyrażenia, przysłowia i powiedzonka trącące błazeństwem pospólstwa, którymi wielu [kaznodziejów] posługuje się czasami na ambonie nie bez wielkiego uszczerbku dla pobożności i nabożnej gorliwości. Nie ma niczego w kazaniach prowadzącego do zgaszenia wszelkiej pobożności, wzbudzenia największej bezbożności u ludzi i pogardy dla całej religii albo raczej jej łatwiejszego utwierdzenia (wzbudzona już bowiem została - o żałości i wstydzie! - w umysłach wielu osób), od tej szalonej i zupełnie nieludzkiej gadaniny tych, którym wydaje się, że głoszą należycie kazania dopiero wtedy, gdy wyżebrawszy sposobność, często jak najdalsi od przedłożonego tekstu, zwyczajem trybuna ludowego podburzają butnie nieświadomy tłum do nienawiści, wyzwisk i prześladowań niewinnych ludzi, a zajmując się z tak gladiatorskimi umysłami sprawą pobożności, bezczeszczą ambonę i miejsca święte oraz odgrywają satyrę i komedię starożytnych na scenach albo w teatrach, skłonni zwłaszcza do kłótni i obelg; św. Jakub nazywa tę gadaninę w swoim liście „mądrością szatańską” [Jk 3,15]. ${ }^{19}$

W dalszej części wywodu podaje Keckermann przykład praktycznego zastosowania reguł inwencji tekstowej, przywołując łatwo rozpoznawalne frazy wyjęte z Ewangelii:

Skoro używają w ten sposób oszczerstwa zamiast miłosierdzia i zębów zamiast języka, cóż innego czynią niż to, że wzniecają spór ze sporu, aby

19 "Quia enim concionis finis est animos auditorum ad religionem et sanctimoniam vitae commovere, ideo omnia ea cavenda erunt, quae huic scopo adversantur, quales sunt ioci, ridiculae ac fabulosae narrationes, dicendi formulae leviores, proverbia et dicteria vulgi scurrilitatem resipientia, qualibus quidem non pauci pro suggesto utuntur subinde non sine magno pietatis et devotae attentionis detrimento. Verum nihil est ad omnem in concionibus devotionem extinguendam adeoque summam in populo profanitatem ac totius religionis contem[p]tum excitandum vel potius confirmandum (iam enim proh dolor et pudor in plurimorum animis excitatus est) proclivius, rabida illa et plane canina loquentia eorum, qui tum demum sibi concionari videntur probe, quando emendicatis occasionibus, a textu proposito saepe alienissimis, tribunitio ritu popellum imperitum seditiose concitant ad hominum innocentium odia, convicia, persecutiones, atque ita gladiatorios in negotio pietatis animos gerentes, suggestum et loca sacra profanant faciuntque satyrae et comoediae veterum scenas aut theatra, ingeniosi scilicet ad rixas et invectivas, quam diabolicam sapientiam divus lacobus in sua epistola appellat", RE, s. 37. 
ciało Kościoła Ewangelickiego nigdy nie złączyło się i było jednomyślne, źli uczniowie Tego, który każe uczyć się od siebie pokory [Mt 11,29]? On nakazuje mianowicie, aby byli pokojem świata [J 14,27], a oni są pochodnią; zachęca, aby byli światłością świata [Mt 5,14], a oni są utrapieniem; napomina wreszcie, aby byli solą ziemi [Mt 5,13], a oni są żółcią i tym, czym jest żółć w ludzkim ciele, tym oni są w ciele Chrystusa. I któż przekona się w swej duszy, że duch Chrystusa, od którego nie ma niczego łagodniejszego, przebywa w takich sercach, skąd wypływa taka gorycz obelg? „I duch ewangelicki ma swą gwałtowność”, słyszę; ale zupełnie inną. Nie zniknął jeszcze, dobry Boże, tak bardzo ów miód miłosierdzia, którym trzeba doprawić aloes najsłuszniejszej nagany. Lecz ci nie mają żadnej słusznej przyczyny do unoszenia się gniewem a w czasie tego uniesienia tak bardzo potępiają niewinnych, że nie zobaczysz $w$ tak niezwykle rozwlekłych wywodach żadnej kropli czy domieszki chrześcijańskiego miłosierdzia czy pokory. Lecz przejdę z kolei do innej rzeczy: nadejdzie bowiem kiedyś ów dzień, gdy Pan upomni się o swą sprawę w ten sposób, że te łzy, które pobożni i niewinni mężowie wylewają za religię i pokój w Kościele, okażą się wylane nad głowami tych, którzy aby zaspokoić swe żądze, nie dostrzegają tego, czego wymaga Bóg i czego wymagają potrzeby Kościoła. ${ }^{20}$

W okresie reformacyjnych sporów kazanie stało się również narzędziem propagowania odnowionej nauki Chrystusa i polemiki z jej krytykami.Uległo tym samym wielu przeobrażeniom inwencyjno-elokucyjnym. Jednym z nich było wyraźne oddalenie się od modelu homiletycznego, w którym stanowiło

„Nimirum dum ita calumniam pro charitate, dentem pro lingua usurpant, quid efficiunt aliud, quam quod litem ex lite ferunt, ne coeat umquam et conspiret Evangelicae Ecclesiae corpus, mali discipuli illius qui a se mansuetudinem iubet disci? Is nimirum mandat, ut sint mundi pax, at illi fax sunt; hortatur, ut sint lux mundi, at illi crux sunt; monet denique, sint sal terrae, at illi fel sunt et quod cholera est in corpore humano, id illi sunt in corpore Christi. Et quis persuadeat animo suo Christi Spiritum, quo nihil mitius inhabitare pectora illa, unde tanta scatet convitiorum amarulentia? At habet et Spiritus Evangelicus suam vehementiam: audio, sed aliam longe, Deus bone, nec usquam abest mel illud caritatis, quo obiurgationis etiam iustissimae aloen condiat. Sed isti nec iustam ullam habent debacchandi causam et inter debacchandum ita extreme innocentes damnant, ut nullam videas in tam prolixis declamationibus Christianae charitatis aut mansuetudinis asperginem vel condimentum. Sed pergo porro ad alia: erit enim aliquando iste dies, cum Dominus causam suam vindicabit, ita ut illae ipsae lacrimae, quas viri pii et innocentes pro religione proque Ecclesiae pace profundunt, in eorum capita effusae appareant, qui, ut suas cupiditates expleant, quid Deus, quid Ecclesiae necessitates postulent, nolunt animadvertere", RE, s. 37-38. 
przede wszystkim komentarz do tekstu biblijnego. Krytyka Keckermanna pod adresem współczesnych mu mówców kościelnych, czyniących z ambony miejsce głoszenia nowych poglądów religijnych i zaciętej walki z ich przeciwnikami, a także wprowadzenie kategorii inwencji tekstowej, podkreślającej niemal genetyczny związek między kazaniem a Pismem, wyrastały z pragnienia odrodzenia kaznodziejstwa w duchu hermeneutyki biblijnej. Motywem przewodnim retoryki kościelnej staje się w ten sposób wezwanie: z powrotem do tekstu Pisma.

Inwencja tekstowa to w ujęciu Keckermanna złożony i wieloetapowy proces wiązania idei odkrywanych w lekturze Biblii z kolejnymi argumentami. Składa się ona z pięciu części ${ }^{21}$, które łączą ściśle kompetencje heremeutyki biblijnej z inwencją na gruncie tradycyjnej retoryki. Są nimi: rozmyślanie nad znaczeniem tekstu, podział i przedłożenie tematu, wyjaśnienie sensu niektórych słów, zwłaszcza wieloznacznych tropów i figur, amplifikacja retoryczna oraz hermeneutyczna zasada aplikacji. Każda z tych umiejętności ma charakter hermeneutyczno-retoryczny, tzn., że może zostać wykorzystana zarówno w trakcie interpretacji tekstu biblijnego, jak i tworzenia mowy kościelnej. Keckermann przeniósł bowiem podstawowe pojęcia ze słownika inwencji do opisu egzegezy Pisma. Stał się w ten sposób orędownikiem takiej lektury retorycznej, która akcentuje odwracalność i przechodniość niektórych form dyskursywnych, np. amplifikacji czy aplikacji.

Wiele miejsce poświęca gdański humanista problematyce poruszania słuchaczy i wzbudzania uczuć. To jedna z najważniejszych powinności kaznodziei, opisana triadycznym schematem: kto porusza - kogo - w jaki sposób czy też dzięki czemu. Bez oddziaływania na emocje słuchaczy i psychagogii (Platon, Fajdros 261b), czyli prowadzenia dusz ludzkich za pomocą mów wszystkie rzeczy, których naucza sztuka wymowy, są daremne ${ }^{22}$. Umiejętność ta wymaga uwzględnienia okoliczności przemowy, rodzaju audytorium i celu perswazji (uczucia gwałtowne i łagodne). Trzeba uważać, aby nie wzbudzać uczuć przeciwstawnych w jednym kazaniu, przechodząc przykładowo nagle i niespodziewanie od smutku do radości. Pośród afektów umieszcza Keckermann przyjemność (delectatio), płynącą z inwencji ukierunkowanej na

21 "Caeterum inventionis textualis partes sunt quinque: 1. praecognito textus, 2. partitio et propositio, 3. explicatio verborum, 4. amplificatio, 5. applicatio", RE, S. 38.

22 "Quin imo si totam rationem eloquentiae in genere spectemus, praecipuam in ea partem obtinent affectus, unde Plato in Phaedro et Gorgia: sine motu affectuum et $\psi v \chi \alpha \gamma \omega \gamma$ jí $\alpha$ inania sunt omnia, quae in rhetorica traduntur", RE, s. 44-45. 
niezwykłość i elokucji odpowiedzialnej za ozdoby językowe. Retoryka czerpie swą afektywną siłę z amplifikacji, zwłaszcza okazałości i uobecnienia danej rzeczy, jak w przypadku unaocznienia (hypotypozy, repraesentatio) ${ }^{23}$, kiedy stawiamy ją za pomocą szczegółowego opisu albo sugestywnego obrazu niejako przed oczami słuchaczy.

Pierwszy etap inwencji tekstowej stanowi namysł nad znaczeniem wybranego fragmentu z Pisma wraz z rozpoznaniem jego struktury retorycznej:

Rozmyślanie jest starannym rozważeniem celu tekstu i jego środków. Trzeba, aby było ono przedsięwzięte w milczeniu i przeprowadzone w umyśle przez tego, kto będzie musiał skutecznie głosić kazania. Skoro wszystkie środki oceniane są bowiem i określane na podstawie celu, to trzeba przede wszystkim, aby cel tekstu i rodzaj materii zostały rozważone z wielką uwagą przez kaznodzieję, gdyż w ten sposób mniej pobłądzi w wyjaśnianiu znaczenia tekstu i łatwiej wynajdzie te wszystkie rzeczy, które należą do jego amplifikacji i aplikacji²4.

Powyższy opis staje się o wiele bardziej zrozumiały w kontekście kolejnych definicji i rozróżnień zaproponowanych przez gdańskiego humanistę. Każdy tekst biblijny ma bowiem charakter uniwersalny (ogólny) albo szczegółowy, czyli historyczny ${ }^{25}$. W pierwszym przypadku traktuje ogólnie o danej rzeczy, w drugim - przedstawia wydarzenia, biorące w nich udział osoby i okoliczności. Ponadto tekst Pisma określony jako uniwersalny może być dydaktyczny (uczący o artykułach wiary, toposach teologicznych, osobie albo działalności Chrystusa), praktyczny (związany z afektywnym oddziaływaniem na czytelnika) albo mieszany (służący częściowo nauce, a częściowo poruszaniu uczuć).

23 "Moventur affectus duplici ratione: magnitudine et praesentia, seu, ut magis perspicue dicam amplificatione sive exaggeratione et denique hypotyposi, id est repraesentatione, si videlicet ita res et personae suis descriptionibus et imaginibus ante oculos ponantur, ut non tam dici, quam geri in praesentia videantur", RE, S. 53 .

24 „Praecognitio est textus quoad scopum et media scopi attenta consideratio. Hanc necesse est tacite animo formari et praconcipi ab eo, qui recte concionem sit habiturus. Cum enim omnia media fine mensurentur et regantur, oportet inprimis finem textus et genus materiae magno iudicio a concionatore expendi, ita enim et minus errabit in textus sensu explicando et facilius omnia inveniet, quae ad eius amplificationem et applicationem pertinent", RE, s. 39.

25 "Omnis autem textus Sacrae Scripturae est vel universalis, vel singularis sive historicus. Universalis textus est, qui de re ipsa generatim tractat, non describens personam aut historiam. Estque vel didacticus, vel practicus, vel denique mixtus", RE, s. 39. 
Biblijne fragmenty pełniące funkcję dydaktyczną tworzą dwie grupy. W pierwszej znajdują się teksty, których temat Keckermann określa jako prosty. Wyjaśnienie przedmiotu takiego tekstu wiąże się z określeniem jego natury za pomocą np. kategorii przyczyny czy skutku. Ten rodzaj występuje najczęściej w Piśmie Świętym, zwłaszcza w opowieściach o stworzeniu, upadku człowieka, wierze, sakramentach, cudach i dobrych uczynkach. Temat we fragmentach dydaktycznych może być złożony; zostaje wówczas połączony konkretnym zagadnieniem doktrynalnym, które organizuje cały proces tworzenia argumentacji (afirmacja tezy albo jej refutacja). Z podanych przez Keckermanna przykładów wynika, że nie chodzi tu o mechaniczne posłużenie się biblijnym cytatem jako dodatkowym dowodem wspierającym bądź osłabiającym jakieś twierdzenie, ale o odnalezienie i zrekonstruowanie takiej strategii retorycznej w analizowanych fragmentach Pisma. Święty Paweł dowodzi np. w Liście do Rzymian (Rz 1-2) tezy głoszącej, że wszyscy ludzie są nędzni, a w Liście do Galatów (Gal 3) wykazuje fałszywość przekonania, że dostępujemy usprawiedliwienia dzięki obrzezaniu i przepisom prawa.

Opracowanie tekstów, które pełnią funkcję dydaktyczną, składa się $\mathrm{z}$ trzech etapów. Pierwszym $\mathrm{z}$ nich jest odwołanie do metody (revocatio ad methodum), polegające na wynalezieniu odpowiedniego "miejsca wspólnego" w postaci zagadnienia teologicznego (loci theologici) albo artykułu wiary, do którego odnosi się interpretowany tekst. Następnie pojawia się rozwiązanie (resolutio), tzn. wyodrębnienie poszczególnych argumentów, które rozwijają temat. Niebagatelną rolę odgrywa tu znajomość logiki, zwłaszcza terminów, rodzajów argumentów (dowodzących, odpierających i powiększających daną tezę) oraz schematów rozumowań sylogistycznych. I wreszcie całą procedurę zamyka wybór (delectus), który wiąże się z nadaniem kazaniu stosownej formy retorycznej, pozwalającej odróżnić tego rodzaju mowę od zwykłego wykładu.

W komentarzu do praktycznego wykorzystania tekstu Biblii zwraca Keckermann uwagę na kwestię poruszania odbiorców. Sięga przy tym po terminologię retoryczną, aby analizować znaczenia ksiąg biblijnych:

Tekst praktyczny w Piśmie Świętym przynależy przede wszystkim do rodzaju doradczego i sądowego, gdyż jest doradzaniem albo odradzaniem, upomnieniem albo skarceniem, albo wreszcie pocieszeniem. Rodzaj popisowy lub pochwalny występuje rzadko i w kościołach ewangelickich nie jest zbyt często używany, a jeśli już to w kazaniach pogrzebowych. Niektórzy Ojcowie wyróżniali się szczególnie w tym rodzaju, gdy pisali 
pochwały męczenników, a także kaznodzieje papiescy, gdy wysławiają często nieumiarkowanie ponad potrzebę zasługi świętych. ${ }^{26}$

Perspektywa genologiczna pozwala na klasyfikowanie poszczególnych fragmentów Pisma Świętego z uwagi na jego strukturę retoryczną oraz pełnione funkcje. Większość z nich dotyczy jednak strategii retorycznych związanych $\mathrm{z}$ rodzajem doradczym. Określenie rodzaju przekłada się z kolei na serię szczegółowych dookreśleń dotyczących m.in. sposobów argumentacji, rodzajów amplifikacji czy stylistycznego rejestru tekstu (styl średni). Warto zwrócić uwagę na dużą powściągliwość humanisty w stosunku do rodzaju popisowego, którego retoryka sprzyja krasomówczemu popisowi kaznodziei.

Interesująco przedstawia się wyliczenie kolejnych etapów interpretacji fragmentów biblijnych, określonych jako historyczne, czyli takich, które „zawierają narrację o przeszłych wydarzeniach”. Teksty tego rodzaju można interpretować w dwojaki sposób. Pierwsza interpretacja ma charakter analityczny i opiera się na retoryczno-logicznym opisie struktury narracji historycznej (partes narrationis) ${ }^{27}$. Koncentruje się dlatego wokół podmiotu, który działał albo czegoś doznawał, okoliczności czasu i miejsca, przyczyn sprawczych i nadrzędnych, zdarzeń poprzedzających, a także skutków wydarzenia i jego konsekwencji. Druga interpretacja uzupełnia tę analizę strukturalną i znacznie pogłębia semantycznie dzięki ujęciu syntetycznemu ${ }^{28}$, pozwalającemu przejść od konkretnego i jednostkowego zdarzenia, osadzonego w określonym kontekście historycznym, do jego sensu uniwersalnego, uogólnionego do postaci pewnej prawidłowości albo prawdy obowiązującej semper ubique. Prawomocność tej operacji hermeneutycznej gwarantuje

26 "Textus practicus in Sacra Scriptura potissimum pertinet ad genus causae deliberativum et iudiciale, siquidem est vel adhortatio et dehortatio, vel obiurgatio aut correptio, vel denique consolatio. Genus demonstrativum vel laudatorium raro occurrit et in Ecclesiis Evangelicis non admodum frequentatur, nisi forte parce in concionibus funebribus. Patres nonnulli valde in hoc genere luxuriant, quando encomia martyrum scripserunt et pontificii, cum divorum laudes extollunt, saepe quam decebat, immoderatius", RE, s. 45.

27 "Expenduntur partes narrationis si consideretur 1. subiectum, quod egit vel passim est, 2. adiacentia, seu circumstantiae loci et temporis, 3. causae impulsivae et instrumentales, 4. antecedentia, 5. effectus, eventus et consequentia", RE, s. 61.

"Revocatio ad generalem thesin fit, cum concionator cogitat in quo genere rerum cuius actio aut passio narratur in quo statu hominum sit persona, quo rem gessit vel passa est. Ut: David adulterium commisit et regno pulsus est; adulterium est in genere peccati, regno exui in genere gravissimarum poenarum. David sub statu seu genere magistratus. Hinc generalis thesis: ergo omnis magistratus graviter peccans, graviter punitur", RE, s. 61. 
według humanisty forma rozumowania sylogistycznego. Oto podany przez niego przykład związany z historią króla Dawida. Przesłanka pierwsza: Dawid popełnił cudzołóstwo i został wygnany z królestwa. Definicja pomocnicza terminów: cudzołóstwo uważa się powszechnie za grzech, a utrata królestwa to jedna z najcięższych kar. Przesłanka druga: Dawid zajmował pozycję urzędnika. Uogólniona konkluzja: Każdy urzędnik, który ciężko grzeszy, będzie ciężko ukarany.

Zagadnienie podziału (partitio) dotyczy dyspozycji określonej jako tekstualna. Obejmuje interpretowany tekst i tworzone na jego podstawie kazanie. Wszelkie podziały powinny służyć ekspozycji znaczenia objaśnianego fragmentu. Keckermann zaleca, aby unikać dzielenia mowy kościelnej na zbyt wiele części, gdyż obciąża to niepotrzebnie pamięć mówcy i słuchacza, a poza tym poważnie utrudnia wzbudzanie uczuć. Przejście od jednego segmentu kazania do drugiego wymaga bowiem z jednej strony stłumienia afektywnego impetu a potem "nabrania jakby nowego ducha"29 $\mathrm{z}$ drugiej zaś uruchomienia bardziej skomplikowanych strategii amplifikacji, aby utrzymać się na tym samym albo zbliżonym poziomie stylistycznej wzniosłości. Za najważniejsze wśród figur tranzycji uznaje humanista uprzedzenie (prolepsis) i pytanie retoryczne.

Kolejny etap, czyli wyjaśnienie słów (explicatio verborum), odnosi się zgodnie z podziałem występującym w retorycznej nauce o formach wysłowienia (elokucji) do słów prostych i złożonych. Oprócz parafrazy wymienia Keckermann wśród sposobów eksplikacji językowej odwołanie do tekstu źródłowego Pisma, hebrajskiego albo greckiego (revocatio ad fontes), definicję nominalną, podstawienie (substytucję) słowa właściwego i częściej używanego w miejsce tropu albo figury, synonimię gramatyczną i interpretację wyrażenia wieloznacznego. W przypadku słów niejasnych szczególne zastosowanie znajduje reguła sformułowana przez Filipa Melanchtona, „geniusza jasności” (perspicuitatis genius): słowa należy rozumieć na podstawie przedłożonej materii. W praktyce oznacza to odwołanie do nauki chrześcijańskiej albo zagadnień teologicznych, np. kwestii sakramentów. Trudno zrozumiałe miejsca Pisma nabierają w ten sposób znaczenia w świetle prawd wiary.

29 "[...] post etiam minus est accommodata ad affectus movendos et fit concio intercisa, frigida, ingrata, quia semper una parte absoluta, dum a re alia ad aliam diversam transitum facimus, oportet impetum affectuum deponere et novum quasi spiritum sumere; adeoque necesse est impediri amplificationes rerum grandiores et longiores, quae solae affectus potissimum commovent $[. . .]^{\prime \prime}$, RE, s. 62 . 
Interpretacja powinna zdaniem Keckermanna uwzględniać intencję (zamysł) autora. Humanista zauważa, że kaznodzieje scholastyczni i papiescy wyróżniają dwa podstawowe poziomy znaczeń biblijnego tekstu, a mianowicie sens literalny (historyczny, dosłowny) oraz mistyczny. W obrębie tego drugiego wyodrębniają alegorię (odniesienie sensu dosłownego do Chrystusa lub kościoła), tropologię (odniesienie sensu literalnego do obyczajów) i anagogię (odniesienie sensu dosłownego do kwestii życia wiecznego), np.:

Tak szabat w sensie alegorycznym wyraża trzydniowy odpoczynek Chrystusa w grobie, w sensie tropologicznym odpoczynek pobożnych od niewolniczych uczynków ciała, i wreszcie w sensie anagogicznym odpoczynek życia wiecznego. ${ }^{30}$

Wszystkie trzy odmiany sensu mistycznego dają się jednak sprowadzić w przekonaniu Keckermanna do alegorii, umożliwiającej niekiedy daleko idące przekształcanie znaczenia dosłownego zgodnie ze strukturą retoryczną tej formy językowej. Tropologia i analogia są bowiem podobnie jak alegoria odmianami sensu niedosłownego, ukrytego pod literą. Ujmując rzecz jeszcze inaczej, pierwsza z nich jest alegorią związaną z obyczajami, druga zaś - alegorią obrazującą życie ludzkie po śmierci. Warto przy tym pamiętać według humanisty o ważnym napomnieniu św. Hieronima: Alegorię należy rozumieć nie na podstawie intencji czytelnika, ale na podstawie autorytetu piszącego. Powołując się na św. Tomasza z Akwinu, Keckermann podkreśla, że argumenty osnute wokół interpretacji alegorycznych (interpretationes allegoricae) niczego same nie dowodzą.

Dopełnieniem zarysowanej hermeneutyki są inne dobrze znane reguły egzegetyczne, takie jak: odwołanie do kontekstu, zwłaszcza miejsca i czasu, opatrzone patrystyczną maksymą: okoliczności oświetlają słowa Pisma; przywołanie podobnych miejsc z ksiąg biblijnych zgodnie z zasadą św. Augustyna: Trzeba na podstawie wielu słów rozumieć słów niewiele; uwzględnienie zbliżonych do siebie odczytań pozostawionych przez wybitnych autorów, np. Ojców Kościoła (interpretatio ex consensu); i wreszcie wyjaśnianie miejsc niejasnych przez bardziej jasne. Część z tych przepisów zawdzięcza Keckermann erudycji patrystycznej, część - znajomości rozpraw współczesnych mu

30 "Sic Sabbatum sensu allegorico figurat Christi quietem triduanam in sepulcro, sensu tropologico quietem piorum a servilibus carnis operibus, sensu denique anagogico, quietem vitae aeternae", RE, s. 68. 
humanistów zainteresowanych hermeneutyką biblijną z Melanchtonem na czele. Wszystkie one sytuują interpretację Pisma w samym centrum inwencji retorycznej.

Niezwykle dużo uwagi poświęca Keckermann amplifikacji, odgrywającej ważną rolę w poruszaniu uczuć u słuchaczy. Obejmuje ona prostą dylatację polegającą na zwiększeniu ilości słów i argumentów (zmiana ilościowa) oraz egzagerację związaną z użyciem tropów i figur wzniosłości retorycznej (zmiana jakościowa).W pierwszym przypadku powiększenie dotyczy materii kazania, w drugim - jego rejestru stylistycznego. Najprostszą techniką amplifikacji jest cytowanie Pisma, rzadziej pism Ojców Kościoła. Przywoływane miejsca powinny zostać rozmieszczone w mowie kościelnej równomiernie, aby pozwoliły jeszcze bardziej uwydatnić znaczenie omawianego tekstu. Podstawę amplifikacji dotyczącej ilości argumentów stanowią niektóre toposy inwencyjne, opisywane przez Keckermanna za pomocą następujących kategorii logicznych: rzecz jednostkowa (egzempla zaczerpnięte z historii świętej), przyczyna, skutek, poprzednik i następnik (okoliczności miejsca i czasu), część (enumeracja), opis (hypotypoza, unaocznienie rzeczy albo osoby), porównanie (podobieństwo), antyteza, czyli przeciwieństwo (prolepsis) ${ }^{31}$. O ile jednak logik korzysta z toposów jako sprawnych narzędzi służących odkrywaniu prawdziwych twierdzeń, o tyle mówca kościelny używa ich jako gotowych struktur pojęciowych, umożliwiających zwiększenie zgromadzonego materiału argumentacyjnego i językowego.

Ostatnim etapem inwencyjnego opracowania kazania jest aplikacja, tzn. dostosowanie (accomodatio) znaczenia omawianego tekstu do aktualnych potrzeb słuchaczy. Przybiera ona postać interpretacji szeroko rozumianego kontekstu komunikacyjnego, zmierzającej do ustalenia, kto, do kogo, kiedy i w jakim stanie rzeczy, a także w jakim miejscu mówi w analizowanym fragmencie Pisma ${ }^{32}$. Na tej podstawie można odnieść dopiero słowa Pisma do

31 "Haec amplificatio sumitur ex locis, quos vocant inventionis, ex quibus tamen non omnes aeque ad amplificandum apti sunt, sed hi octo potissimum: 1. ex individuis, seu exemplis, 2. ex causis, 3. ex effectibus, 4. exantecedentibus, consequentibus et connexis, 5. ex partibus, 6. ex descriptione, 7. ex comparatis, 8. ex antithesi, seu oppositis, quo et prolepsis pertinet. Logicus locos inventionis simpliciter considerat, quatenus ad veritatis notitiam pertinent, sed rhetor eos applicat ad usum amplificatonis et exaggerationis, quam logicus qua logicus non curat", RE, s. 76.

„Applicationes facile inveniuntur, si consideres haec quattuor in textu proposito: 1. a quo, 2. ad quem, 3. quando et quo rerum statu et denique quo loco quidlibet dicatur. Caeterum applicatio haec quae deductione consequentiae fit, est vel ad fidem, vel ad consolationem, vel ad vitae institutionem", RE, s. 94 . 
spraw wiary, pocieszenia i nauki o dobrym życiu. W pierwszym przypadku kaznodzieja powinien sięgać częściej po afirmację (dowodzenie) niż refutację. Wybór strategii retorycznej ma być bowiem motywowany przedłożonym tekstem. Odpierając fałszywe twierdzenie, można „ze spokojem i bez żadnych oznak poruszenia" powoływać się na słowa Biblii, uzgodnione ze sobą miejsca, poprawnie wyciągnięte wnioski, analogie do całej doktryny i artykułów wiary, zezwolenia i zeznania, absurdalność i sprzeczność sądów adwersarza, stanowisko Kościoła. W przypadku konsolacji, potrzebnej niemal w każdym kazaniu, gdyż właściwej Ewangelii jako dobrej nowinie, mówca kościelny utwierdza słuchacza w przekonaniu o Bożej miłości i miłosierdziu. I wreszcie w ostatnim przypadku kaznodzieja wzywa do nawrócenia i pokuty. Za każdym razem znaczenie tekstu biblijnego odnosi się bezpośrednio do głównego celu kazania.

Dwiema ostatnimi częściami „tekstowego" kazania są dyspozycja i elokucja, określona jako ozdobienie mowy za pomocą tropów i figur. Keckermann wyróżnia trzy podstawowe części kazania: krótki wstęp, omówienie (tractatio) danego fragmentu Pisma i zwięzłe zakończenie. Szczególnymi ornamentami mowy kościelnej są zdaniem gdańskiego humanisty prostota wysłowienia, jasność stylu, zasobność (copia) słów, siła ekspresji językowej (efficacia) i figury retoryczne:

Figuratywność języka nazywa się właściwie ozdobnością mowy, która znajduje się w pojedynczych albo złożonych słowach. Ozdobność słów pojedynczych dotyczy tropów, z których kaznodzieja używa przede wszystkim metafory, ponieważ ten trop jest najpiękniejszy spośród wszystkich i odpowiedni do poruszania i sprawiania przyjemności. W przypadku słów złożonych, czyli sentencji trzeba, aby mówca używał przede wszystkim jedenaście schematów, czyli figur: wykrzyknienie, pytanie retoryczne, apostrofa, nagana, zaklinanie, wezwanie i przemowa do sumienia, życzenie, zdumienie, prozopopeja, dialogizm, zawieszenie. ${ }^{33}$

33 „Figuratio sermonis est orationis ornatus proprie dictus, qui est vel simplicium, vel coniunctorum verborum. Simplicium verborum ornatus est in tropis, ex quibus metaphora potissimum concionator utetur, siquidem tropus is est omnium florentissimus et ad movendum delectandumque accommodatus. [...] In coniunctis vocibus seu sententiis undecim potissumum schemata seu figurae concionatori sunt usurpandae: 1. exclamatio, 2. interrogatio, 3. apostrophe, 4. compellatio, 5. obsecratio, 6. adiuratio et compellatio conscientiae, 7. optatio, 8. admiratio, 9. prosopopoeia, 10. sermocinatio, 11. sustentatio", RE, s. 112-113. 
Sojusznikiem Keckermanna w dziedzinie ozdobności jest św. Augustyn, który w rozprawie o nauce chrześcijańskiej napominał, aby „mąż kościelny” omawiał słowa Pisma nie tylko mądrze, lecz także pięknie i ozdobnie. Inwencyjne uzależnienie kazania od ksiąg biblijnych pociąga za sobą czerpanie z nich również stylistycznych wzorców w zakresie prostoty i ozdobności językowej. Postulat naśladowania figur służących amplifikacji i poruszaniu słuchaczy, np. apostrof Dawida albo Jeremiasza czy zaklinań św. Pawła, stanowi bezpośrednią konsekwencję myślenia humanisty o kazaniu w kategoriach tekstu-komentarza. Jako uważny interpretator figur Pisma kaznodzieja przemawia do wiernych, używając podobnych form wysłowienia.

Centralną kategorią retoryki kościelnej Keckermanna pozostaje niewątpliwie inwencja tekstowa (inventio textualis), wiążąca wieloetapowy proces przygotowania mowy kościelnej z uważną lekturą i interpretacją Pisma Świętego. Ta hermeneutyczna orientacja sztuki wynajdowania argumentów wyrasta $\mathrm{w}$ prostej linii z dychotomicznego podziału homiletyki, który zaproponował św. Augustyn. W ujęciu humanisty ulega ona jednak znaczącemu rozwinięciu i pogłębieniu. Epitet „tekstowa”, którym opatruje on konsekwentnie inwencję, służy usytuowaniu wszelkich strategii retorycznych (amplifikacji, aplikacji i figuratywności) w otwartym polu biblijnej intertekstualności. Ma skutecznie przypominać mówcy o potrzebie nieustannego odniesienia do Pisma, ujmowanego jako inwencyjny i elokucyjny architekst, tekst semantycznie źródłowy, uniwersalny pre-tekst i kontekst. Pozwala również wytłumaczyć obecność licznych intertekstów z Biblii w mowie kościelnej. Kaznodzieja powinien bowiem tworzyć kazanie na wzór i podobieństwo tekstu biblijnego.

Inwencja tekstowa pozwala autorowi ustanawiać rozmaite zależności tekstowe. Można - jak sądzę - wyróżnić pośród nich dwa rodzaje. Relacjami o charakterze alegacji są wszystkie cytaty i aluzje do Pisma, nadające znaczenia kazaniu iure auctoritatis. „Kto przemawia, niech mówi jakby słowa Boże" (1 P 4,11). Przywołany fragment staje się w tym przypadku zwornikiem znaczeń nowego tekstu. Wszelkie odwołania do dzieł komentatorów biblijnych tworzą z kolei relacje intertekstualne, uwikłane w twórczą rekontekstualizację czy interpretację. Ich wartość semantyczna była poza tym wyraźnie zróżnicowana. Przywołanie słów któregoś z ojców Kościoła, np. św. Augustyna czy św. Hieronima, miało bowiem dla renesansowego kaznodziei zupełnie inną wartość perswazyjną niż cytat ze współczesnego mu egzegety. Wybitni i szczególnie uzdolnieni retorycznie twórcy stawali się auctores, przedstawicielami gwarantującej prawdziwość tradycji. 
W dobie reformacyjnych sporów i kontrowersji teologicznych, w których słowa Pisma, wyrwane często z macierzystego kontekstu, stawały się niejednokrotnie orężem zaciętej walki między coraz bardziej poróżnionymi w wierze wyznawcami Chrystusa, zaproponował Keckermann kategorię retoryczną, wyznaczającą główny kierunek odrodzenia współczesnego mu kaznodziejstwa. Głosząc wezwanie powrotu do tekstu, humanista odkrywał na nowo patrystyczne reguły egzegezy, uzupełnione spostrzeżeniami późniejszych komentatorów, średniowiecznych jak i wczesnonowożytnych. Święty Augustyn zdawał się w tej sprawie mówić jednym głosem ze św. Tomaszem z Akwinu, a św. Hieronim znajdował godnego następcę w osobie Erazma z Rotterdamu albo Filipa Melanchtona. Wszyscy niezależnie od głoszonych poglądów filozoficznych pozostawali zgodni w kwestii autorytetu Pisma. Wynalezienie inwencji tekstowej i umieszczenie jej w centrum homiletyki pozwoliło Keckermannowi scalić na nowo hermeneutykę z retoryką, połączyć poszukiwanie znaczeń z wynajdywaniem dla nich odpowiedniej szaty słownej, zniwelować pęknięcie między rzeczami a słowami. 


\section{Abstract}

\section{Wojciech Ryczek}

JAGIELLONIAN UNIVERSITY (CRACOW)

Textual Invention: Intertextual Antecedents in the Renaissance

Ryczek discusses the notion of the textual invention (inventio textualis) introduced by the Danzig-born humanist Bartholomew Keckermann (1572-1609) in his handbook to church preaching (Rhetorica ecclesiastica, Hanau 1600). Ryczek's focus is on Keckermann's epithet describing the art of constructing an argumentation - an epithet that stresses its close connection with Biblical hermeneutics. To outline this category Ryczek contextualizes it with a broadly defined return to the sermon as a rhetorically disciplined commentary on a chosen fragment of the Scriptures. The rhetorical reading (interpretation) represents in this concept a hub of the inventive art of discovering new meanings and convincing arguments.

\section{Keywords}

homiletic, Bartholomew Keckermann, invention, intertextuality, elocution, rhetoric 